\title{
TREATMENT OF HIGH-STRENGTH LIQUID WASTES BY AUTO-THERMAL AEROBIC DIGESTION
}

\author{
Peter F. Randerson \\ Timothy P. Higgins \\ Brian N. Dancer \\ Cardiff University, Wales, $U K$
}

\begin{abstract}
Auto-thermal aerobic digesters comprise a simple, robust, inexpensive technology appropriate for on-site liquid waste treatment by small- and medium-sized enterprises. They have been shown to be effective at treating a wide range of effluents and liquors arising from food processing and chemical plants, especially those with high levels of biological oxygen demand (BOD), or for small-scale sewage treatment.

Liquid circulates around the reactor vessel by pumping through a venturi nozzle, which draws air into the flow. As the microbial community develops, the system self-heats and organic matter is removed as $\mathrm{CO}_{2}, \mathrm{NH}_{3}$ and water. The temperature of the insulated vessel may rise to $558 \mathrm{C}$ or more as the thermophilic community becomes established. BOD levels typically reduce by $90 \%$ over a 3-5 day residence time. Auto-thermal aerobic digestion (ATAD) acts faster than mesophilic or anerobic degradation and is very resistant to organic toxins (pentachlorophenol) or metal pollutants $\left(\mathrm{Cu}^{2+}, \mathrm{Zn}^{2+}, \mathrm{Ni}^{2+}\right)$ in the waste.

Examples are shown of wastes and liquors successfully treated by pilot-scale ATAD systems up to 1000 litres in size. These include effluents from food processing (icecream, chocolate, egg pasteurisation, brewing), chemical plants (wood processing, phenolic liquor) and silage pit effluent.

Auto-thermal aerobic digestion offers a versatile, cost-effective solution for liquid waste treament in a climate of increasing demands from Regulatory Authorities and increasing costs of conventional off-site waste disposal such as sewerage or landfill charges.
\end{abstract}

\section{KEYWORDS}

Waste treatment, high-strength effluent, auto-thermal aerobic digestion, biodegradation, bioreactor, venturi aeration, BOD, COD, thermophilic bacteria. 


\section{INTRODUCTION}

Small and medium sized enterprises (SMEs) are seen by the European Union as the engines of economic advance and recovery. In many instances, however, they are meeting increasing demands from Regulatory Authorities and incurring increasing costs in relation to disposal of both solid and liquid wastes. Trade effluents discharged through the sewer system, to landfill or by specialist contractors all attract increasing direct costs and/or taxes. Introduction of new sewage treatment facilities in the UK following EU directives has seen sewerage costs increase up to ten-fold in comparison to charges when sewage was discharged to sea outfalls. Additionally, companies can seek commercial advantage or may be required by their suppliers, to meet the requirements of an internationally recognised environmental management standard such as ISO13001.

The objective of the studies reported here was to develop a low cost, robust technology for on-site effluent treatment to mitigate the costs of empirical charging formulae now used to calculate sewerage charges of SMEs in the UK. Although methods of charging for sewage treatment may differ between countries around and outside the EU, similar problems of liquid waste disposal face all commercial enterprises, and are likely to be economically acute for all SMEs such as food processing plants now or in the near future.

\section{SEWERAGE CHARGES}

In the UK, sewerage costs for trade effluent are calculated by the Mogden formula in which the total charge varies greatly with the strength of the effluent (measured by Chemical Oxygen Demand - COD, and Solids), and with the volume discharged.

$$
C=R+V+B^{*}(O t / O s)+S^{*}(\mathrm{St} / \mathrm{Ss})
$$

Where $\mathrm{C}=$ total charge $\left(\right.$ pence $\left./ \mathrm{m}^{3}\right)$ of trade effluent

(current charges in Wales are shown)

$\mathrm{R}=$ fixed cost for conveyance $\left(18\right.$ pence $\left./ \mathrm{m}^{3}\right)$

$\mathrm{V}=$ fixed cost for pre-treatment $\left(20\right.$ pence $\left./ \mathrm{m}^{3}\right)$

$\mathrm{B}=$ fixed cost for biological treatment $\left(13\right.$ pence $\left./ \mathrm{m}^{3}\right)$

$\mathrm{S}=$ fixed cost for sludge disposal $\left(10\right.$ pence $\left./ \mathrm{m}^{3}\right)$

$\mathrm{Ot}=\mathrm{COD}$ in the effluent $(? \mathrm{mg} / \mathrm{litre})$

Os $=$ COD of "average" settled sewage $(500 \mathrm{mg} /$ litre $)$

$\mathrm{St}=$ Solids value in the effluent $(? \mathrm{mg} /$ litre $)$

$\mathrm{Ss}=$ Solids value of "average" settled sewage $(350 \mathrm{mg} / \mathrm{litre})$

Illustrative example of Mogden formula charges (based on Dwr Cymru, Wales);

\begin{tabular}{|l|l|l|l|}
\cline { 2 - 4 } \multicolumn{1}{c|}{} & COD mg/1 & Solids mg/1 & Charge per $\mathrm{m}^{3}$ \\
\hline a) relatively weak effluent & 5000 & 20 & $£ 1.79$ \\
\hline b) strong effluent & 100000 & 20 & $£ 26.89$ \\
\hline
\end{tabular}

The commercial importance, especially to SMEs, of minimising both COD and Solids in the effluent is clear, if this can be achieved with relatively low capital and running costs. 


\section{AUTO-THERMAL AEROBIC DIGESTERS}

Auto-thermal aerobic digestion represents an innovative and unique system for treatment of high strength wastewaters. It benefits from many of the characteristics of thermophilic composting and sludge digestion. These include faster degradation rates, more efficient removal of free ammonia to the gas phase, inactivation of pathogenic micro-organisms, and a general insensitivity to exposure to heavy metal and organic toxicants when compared to activated sludge processes and anaerobic digestion. The mean residence times for ATAD are substantially reduced when compared to mesophilic processes, which leads to a significant reduction in the size of bioreactors required [1]. The main disadvantages of the process are the expense of tank aeration (electricity), poor bacterial flocculation (but relatively little sludge is produced), and foaming problems (may be overcome with anti-foaming agents).

The bioreactor consists of an insulated barrel shaped vessel, the liquid contents of which are pumped around rapidly near the base [2]. Just prior to re-entry the liquid is forced through a venturi nozzle with air pipe attached (Figure 1). This has the effect of allowing air to be self-entrained into the vessel, maintaining a high concentration of dissolved oxygen. Air is exhausted through a pipe at the top. The random microflora, which develops in such digesters, responds with rapid growth and typically the temperature is elevated (to a maximum of $70{ }^{8} \mathrm{C}$ ) by self heating $[3,4,5]$. The organic component of the feedstock is used for microbial growth but most is exhausted as $\mathrm{CO}_{2}$, some ammonia and water. Model reactors can be 50-100 litres using a 90W pump (domestic central heating pump). A larger experimental scale is 1000 litres, requiring a pump of about 500W [6].

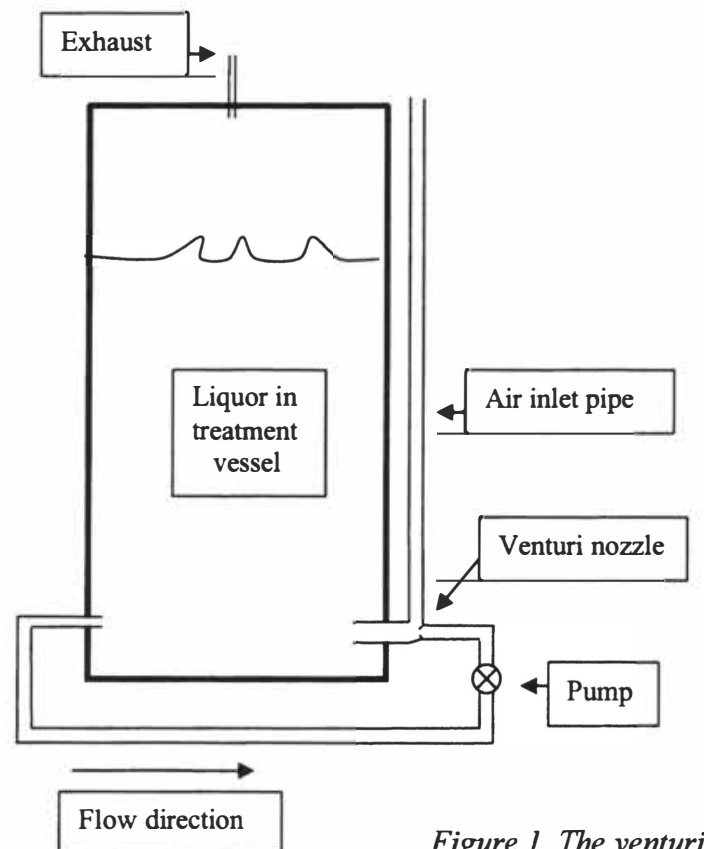

Figure 1. The venturi-aerated digester $[2.6]$ 
KALMAR ECO-TECH'03

Bioremediation and Leachate Treatment

KALMAR, SWEDEN, November 25-27, 2003

The thermophilic microbial community that develops is capable of reducing biological oxygen demand (BOD) by up to $90 \%$ within a 3-5 day residence time in optimised conditions. Such reactor vessels can therefore be much smaller than anaerobic digesters (typically 15-30 days residence time), with savings in land and construction costs. In many trade effluents BOD comprises a very high proportion of the total organic matter (COD), on which sewerage charges would be based. Digesters, if adequately insulated, can be used all year round even in cold climates because of self-heating. Where human or animal waste material is included in a waste stream, strict regulations govern its disposal, requiring heat treatment at more than $55 \mathrm{oC}$. ATAD systems provide such conditions and hence can inactivate potential pathogens and infective agents.

The microbial community has been shown to be resistant to additions of heavy metals $(\mathrm{Cu} 2+, \mathrm{Zn} 2+, \mathrm{Ni2}+)$ and organic toxicants (phenol, pentachlorophenol) at concentrations ten times higher than would poison an activated sludge plant or anaerobic digester [1]. The organic pollutants became rapidly metabolised.

Effluents from food processing often contain high concentrations of sugars and starch which are readily metabolised to organic acids, reducing $\mathrm{pH}$ rapidly below 4 and inhibiting further biodegradation. Adding calcium or sodium carbonate immediately raises $\mathrm{pH}$ and re-starts bacterial degradation, enabling the bacteria to metabolise acidic compounds (lactate butyrate, propionate) and maintaining alkaline $\mathrm{pH}$.

Problems of foaming can be managed during start-up using anti-foam agents and typically diminish on reaching steady state. A special design was developed for effluents rich in water-immiscible oils and fats.

\section{EXAMPLE APPLICATIONS OF ATAD}

Pilot scale trials (50 to 1000 litre vessels) using a range of effluents arising from food processors and chemical manufacturers have demonstrated the potential of ATAD reactors to achieve substantial and rapid reductions of COD/BOD. In most cases, greater efficiency could be achieved by optimising operating conditions, so reducing residence time. This would occur along with scale-up to accommodate the rate of production of a particular effluent. The following examples, shown in summary, illustrate the operation of ATAD systems with a variety of trade effluents. The systems were initially primed by adding a small amount ( $5 \%$ volume) of waste to water or sewage and running the reactor for a few days, after which a substantial amount ( $25 \%$ volume) of waste was added. Levels of COD, solids, $\mathrm{pH}$, temperature, etc were monitored as the reactions proceed in batch mode. In some cases, regular additions of waste were made, to produce a semicontinuous process. Additions of carbonate or growth nutrients were made as appropriate. Initial levels of pollutants refer to the waste before adding it to the reaction vessel. 
KALMAR ECO-TECH'03

Bioremediation and Leachate Treatment

4.1 Chocolate factory effluents

KALMAR, SWEDEN, November 25-27, 2003

\begin{tabular}{|c|c|}
\hline Battermix waste & Comments \\
\hline $\begin{array}{l}50 \text { litre small scale trial. } \\
\text { Initial: } \mathrm{pH} 6.9 \\
\text { COD } 87000 \mathrm{mg} / \mathrm{l} \\
\text { Solids } 334000 \mathrm{mg} / 1 \\
\end{array}$ & $\begin{array}{l}\text { After addition of waste - } \mathrm{pH} \text { dropped to } 4.0 \text { (inhibitory) due to } \\
\text { acid production. Carbonate added to re-activate. } \\
\text { After } 13 \text { days temperature dropped - N \& P nutrients added - high } \\
\text { temperature restored. }\end{array}$ \\
\hline $\begin{array}{l}\text { Final ( } 16 \text { day): pH } 9.5 \\
\text { COD } 7725 \mathrm{mg} / 1 \\
\text { Solids } 9600 \mathrm{mg} / 1\end{array}$ & Mogden sewerage costs: initial $£ 171$, final $£ 23$ per $\mathrm{m}^{3}$ \\
\hline
\end{tabular}

\begin{tabular}{|l|l|}
\hline Marshmallow waste & Comments \\
\hline 50 litre trial & Wash-down from production line (large volume, intermittent flow). \\
Initial: pH 6.4 & pH dropped to 3.3. Carbonate added to re-activate. \\
COD $302500 \mathrm{mg} / 1$ & N \& P nutrients added (day 8). \\
Solids $4872 \mathrm{mg} / 1$ & \\
\hline Final (15 day): pH 8.6 & $\begin{array}{l}\text { Installing an equalisation tank would even out wash-down } \\
\text { COD } 1550 \mathrm{mg} / 1\end{array}$ \\
discharges. \\
Solids $4444 \mathrm{mg} / 1$
\end{tabular}

4.2 Ice-cream factory waste

\begin{tabular}{|l|l|}
\hline Spillage onto factory floor & Comments $\quad$ (see Figure 2) \\
\hline 40 litre trial & In first 24 hours, COD reduced by 53\%, protein by $90 \%$ and \\
Initial: $\mathrm{pH} 6.6$ & $\mathrm{pH}$ dropped to 4.0 (lactate production), then little change. \\
$\mathrm{COD} 254600 \mathrm{mg} / 1$ & \\
Protein $22260 \mathrm{mg} / 1$ & \\
\hline Final $(8$ day): $\mathrm{pH} 7.5$ & $\mathrm{CaCO}_{3}$ added (day 6) - re-starts reaction; $\mathrm{pH}$ increased to 7.6, \\
COD $3890 \mathrm{mg} / 1$ & and further COD reduction. \\
Protein $222 \mathrm{mg} / 1$ & Would give Mogden cost saving per $\mathrm{m}^{3}$ of $\Theta 4 \%$. \\
\hline
\end{tabular}




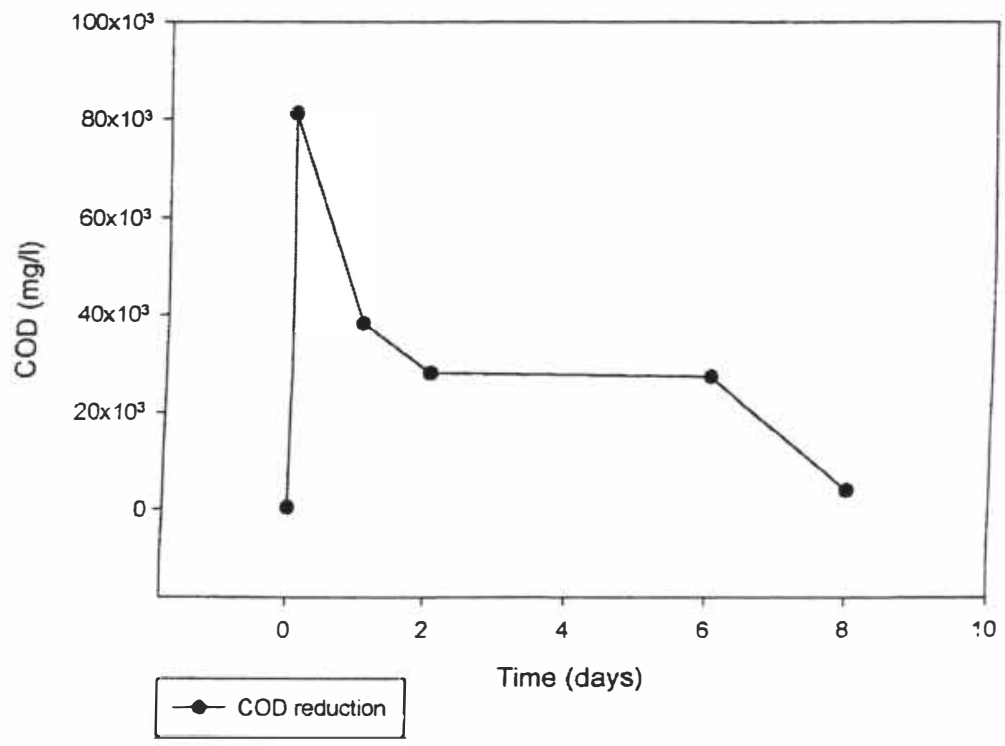

Figure 2. Biodegradation of ice cream waste

\subsection{Egg processing plant effluent}

\begin{tabular}{|l|l|}
\hline Pasteurised egg waste & Comments (see Figure 3) \\
\hline 1000 litre pilot scale trial & High pH due to betol sanitizer used in cleaning process. \\
Initial: $\mathrm{pH} 12.6$ & Continuous input of waste from holding tank (up to 500 \\
$\mathrm{COD} 21000 \mathrm{mg} / 1$ & litres/day). Max. temperature of reactor $51^{\circ} \mathrm{C}$ at day 2. \\
Solids $5244 \mathrm{mg} / 1$ & Waste temperature $80^{\circ} \mathrm{C}$, hence use of fresh waste would assist \\
Protein $17 \mathrm{mg} / 1$ & in generating high temperature (cost-free). \\
\hline Final $(5 \mathrm{day}) \mathrm{pH} 9.6$ & 5-day reductions relative to initial reactor concentrations: COD \\
COD $5980 \mathrm{mg} / 1$ & $49 \%$, Solids $64 \%$, Protein $25 \%$. \\
Solids $1860 \mathrm{mg} / 1$ & Foaming was a problem with this proteinaceous waste. Use of \\
Protein $2 \mathrm{mg} / 1$ & 2 reactors in sequence would reduce foaming. \\
\hline
\end{tabular}


KALMAR ECO-TECH'03

Bioremediation and Leachate Treatment

KALMAR, SWEDEN, November 25-27, 2003

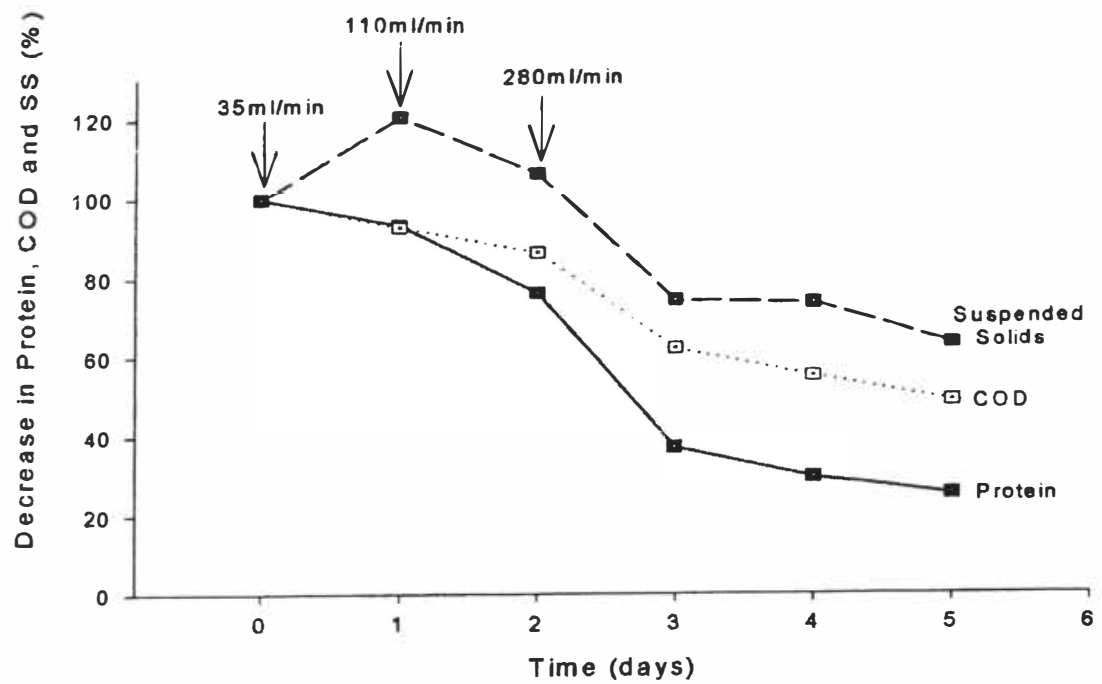

Figure 3. Pilot scale degradation of egg waste

\subsection{Chemical effluent from plastic manufacture}

Due to high levels of methanol and p-hydroxybenzoate, this waste cannot be discharged to sewer and is sent for incineration. Phenolic compounds (degradation products) would inhibit activated sludge plants and anaerobic digesters.

\begin{tabular}{|l|l|}
\hline Fresh waste (no phenolics) & Comments \\
\hline 50 litre trial & Initial large reduction in COD and total organic carbon (TOC) \\
Initial: $\mathrm{pH} 7.3$ & over 8 days. \\
\hline Final: $\mathrm{pH} 9.6$ & Very efficient overall reduction - 95\% over 16 days. \\
COD $1650 \mathrm{mg} / 1$ & \\
TOC $1100 \mathrm{mg} / 1$ & \\
\hline
\end{tabular}

\begin{tabular}{|c|c|}
\hline Stored (phenolic) waste & (see Figure 4) \\
\hline $\begin{array}{l}50 \text { litre trial } \\
\text { Initial: } \mathrm{pH} 5.4 \\
\text { COD } 51-54000 \mathrm{mg} / 1\end{array}$ & $\begin{array}{l}\text { Rapid decrease in methanol and phenol ( } 4 \text { days), eliminated over } \\
11 \text { days, followed by slower reduction of COD }(95 \%) \text { over } 11 \\
\text { days. }\end{array}$ \\
\hline $\begin{array}{l}\text { Final: } \mathrm{pH} 8.3 \\
\text { COD } 1600 \mathrm{mg} / 1 \\
\text { TOC } 600 \mathrm{emg} / 1\end{array}$ & $\begin{array}{l}\text { Presence of phenol reduced bacterial numbers (total viable counts, } \\
\text { TVC) but remaining organisms degraded it using phenol mono- } \\
\text { oxygenase enzyme and TVC rose again. }\end{array}$ \\
\hline
\end{tabular}




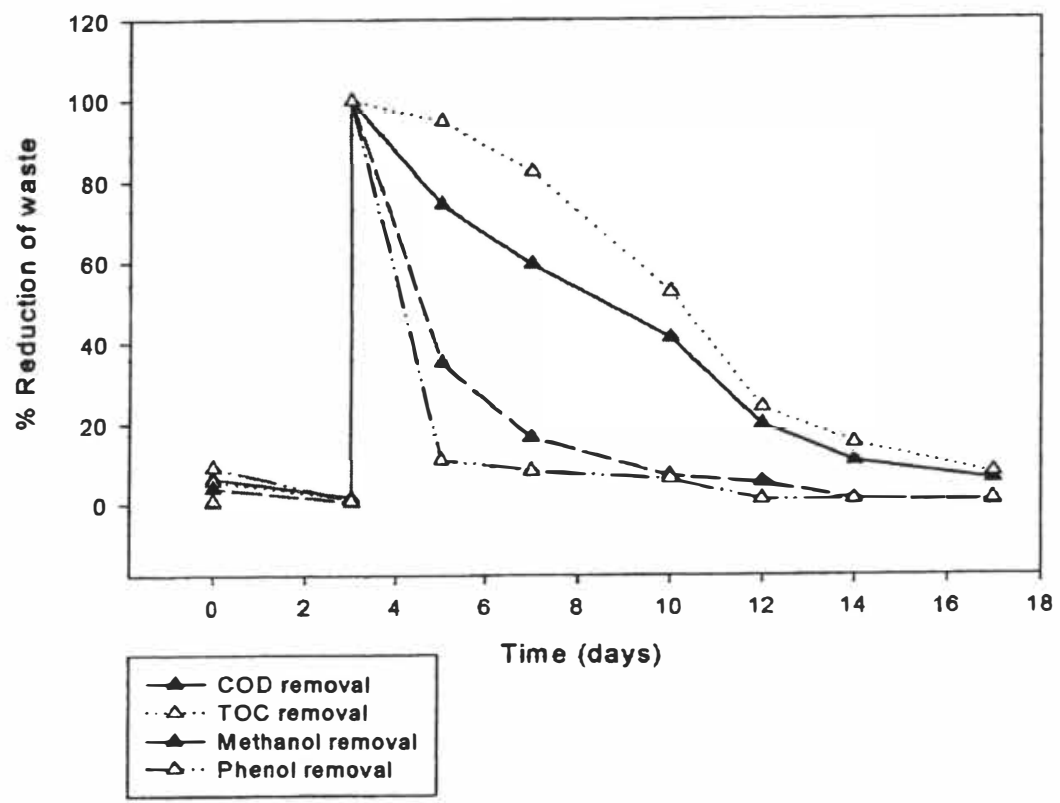

Figure 4. Treatment of phenol-containing chemical waste

\subsection{Wood waste effluent from a board-making factory}

Three distinct effluents were produced by different stages in the manufacturing process. In addition a very strong and acidic evaporate waste was produced (pH 3.6, COD 221 $200 \mathrm{mg} / \mathrm{l})$. Problems of foaming prevented processing of this waste.

\begin{tabular}{|l|l|}
\hline 3 distinct effluents & Comments (effluents arise at different stages in process) \\
\hline Initial; $\mathrm{pH} 5.9-8.2$ & COD reduction in reactors 80-89\%; 50\% reduction typically in first \\
COD $1475-7875 \mathrm{mg} / 1$ & 3 day period. \\
\hline Final: $\mathrm{pH} 8.7-9.0$ & $\begin{array}{l}\text { Indication of nutrient limitation (if added, would increase } \\
\text { COD } 160-380 \mathrm{mg} / 1\end{array}$ \\
\hline
\end{tabular}

\subsection{Silage effluent}

On-farm storage of silage often results in surface leakage of highly polluting effluent. The acid constituents (lactic, butyric and propionic acids) are highly corrosive to concrete containers and silage effluent has extremely high BOD values (up to $90000 \mathrm{mg} / \mathrm{l}$ ). Pollution of surface waters poses a great danger to local aquatic life, and on-site treatment of leachate would mitigate such hazards. 


\begin{tabular}{|l|l|}
\hline Silage effluent & Comments \\
\hline Initial $\mathrm{pH} 3.8$ & No change after extended aeration (microbial inhibition) \\
\hline $\begin{array}{l}\text { Added } 2 \% \mathrm{CaCO}_{3} \\
\text { to raise } \mathrm{pH} \text { to } 4.8\end{array}$ & $\begin{array}{l}\text { Reactor functioned - temperature raised to } 58 \mathrm{C} \text { and } \mathrm{pH} \text { raised to }>8.0 . \\
\text { Bacteria now able to metabolise organic acids (e.g. Bacillus sphaericus, } \\
\text { B. subtilis, } \text { B. licheniformis, known to grow on lactate, acetate, etc). }\end{array}$ \\
\hline $\begin{array}{l}\text { To maintain } \\
\text { alkaline condition: }\end{array}$ & $\begin{array}{l}\text { A continuous feed system could be devised, based on the rate of acid } \\
\text { degradation, with treated effluent applied safely to land. }\end{array}$ \\
\hline
\end{tabular}

\subsection{Brewery waste}

Spent brewery liquor may contain more than $50000 \mathrm{mg} / \mathrm{l} \mathrm{BOD}$. Experimental treatment of weaker effluent (initial BOD after dilution in reactor, $1100 \mathrm{mg} / \mathrm{l} \mathrm{BOD}$ ) achieved a reduction of $50 \%$ over 4 days but the temperature rose to a maximum of just over $508 \mathrm{C}$, reflecting the low strength of this effluent.

\section{CONCLUSION}

Auto-thermal aerobic digestion has proved to be effective for initial treatment of a variety of trade and process effluents including food waste, chemical waste and silage effluent with, potentially, significant savings on sewerage charges. This novel and versatile technology is characteristically:

- Robust - resistant to contamination by metals and organic poisons;

- Low capital cost - simple to construct, requires relatively small housing space;

- Low running costs - electricity for continuous pumping;

- Rapid degradation rate compared to mesophilic aerobic or anaerobic digestion;

- Removal of pathogenic micro-organisms (requires $>55^{\circ} \mathrm{C}$ ).

In view of these features ATAD is particularly appropriate for SMEs requiring on-site pre-treatment of liquid wastes before discharge to municipal sewerage. Two-stage treatment for strong effluents with ATAD followed by "polishing" in reed or willow beds (constructed wetlands), is proposed where direct discharge to environment is required. Further work in collaboration with industry is needed to prove the efficacy and costeffectiveness of full-scale installed ATAD systems.

\section{ACKNOWLEDGEMENTS}

The trials reported here were funded by European Regional Development Fund (ERDF) and Welsh Industry, in support of Cardiff University's Clean Technology Group.

\section{REFERENCES}

[1] Burt, P.F.H. 1990 The microbiology of thermophilic aerobic sewage sludge digestion. Ph.D. Thesis, University of Wales College of Cardiff.

[2] Morgan, S.F., Winstanley, R., Littlewood M.H., \& Gunson, H.G. 1986. The design of an aerobic thermophilic sludge digestion system, p393-402. In: Anon (Ed.) Institution of Chemical Engineers Symposium Series No 96. Pergamon Press, Oxford. 
KALMAR ECO-TECH'03

Bioremediation and Leachate Treatment

KALMAR, SWEDEN, November 25-27, 2003

[3] Sonnleiter, B. and Fiechter, A. 1983a. Bacterial diversity in thermophilic aerobic sewage sludge. I. Active biomass and its fluctuations. Eur. J. Appl. Microbiol. Biotechnol. 18; 47-51. DOI: https://doi.org/10.1007/BF00508 D 8

[4] Sonnleiter, B. and Fiechter, A. 1983b. Bacterial diversity in thermophilic aerobic sewage sludge. II. Types of organisms and their capacities. Eur. J. Appl. Microbiol. Biotechnol. 18; 174-180. DOI: https://doi.org/10.1007 /BF00498 041

[5] Burt, P.F.H., Morgan, S.F., Dancer, B.N. \& Fry, J.C. 1990a. Microbial populations and sludge characteristics in thermophilic aerobic sewage sludge digestion. Appl. Microbiol. Biotechnol. 33, 725-730.

DOI: https://doi.org/10.1007 /BF00604947

[6] Burt, P.F.H.., Littlewood, M.D., Morgan, S.F., Dancer, B.N., \& Fry, J.C. 1990b. Venturi aeration and thermophilic aerobic sewage sludge digestion in small scale reactors. Appl. Microbiol. Biotechnol. 33, 721-724.

DOI: https://doi.org/1 0.1007 /BF00604946 